International Journal of Agriculture, Environment and Bioresearch

Vol. 5, No. 03; 2020

ISSN: $2456-8643$

\title{
SURVEY OF PRIMATES IN TWO SELECTED FOREST RESERVES IN BENUE STATE, NIGERIA
}

\author{
Uloko, I. J' ${ }^{1}$ Orsar, T. $\mathbf{J}^{2}$ And Adendem, M. N ${ }^{3}$ \\ Federal University Of Agriculture,makurdi,benue State, Nigeria
}

https://doi.org/10.35410/IJAEB.2020.5508

\begin{abstract}
This study focused on primate distribution and abundance in yaaiwa and Ipinu-Igede Forest Reserves in Kwande and Oju local Government Areas of Benue State, Nigeria, respectively. The study also assessed the species of tree composition and abundance in addition to types of anthropogenic activities in these areas.
\end{abstract}

The research period was from June, 2018 to May, 2019. The methods used were line transect method to determine their population density and the total enumeration count for plants species composition and abundance. Structural questionnaire were used to obtain information on anthropogenic disturbances in the study areas.

Results revealed that population density of the three species of primates sighted in the study areas were very low, 1.68 individuals $/ \mathrm{km} 2$ due to high rate of anthropogenic activities such as farming, hunting and logging in and around these study areas. However, the presence of three different species of primates such as olive Baboon (Papio Anubis), Patas monkey (Erythrocebus Patas) and Tantatus monkey (Chlorocebus aethiops) were confirmed, through physical observations and indirect indices such as calls, dungs and foot prints. The plant species and ecology of the study areas were mainly of primary forest which was seriously modified through human activities. Clearly, most of the respondents were energetic youths of age between $16-35$ years, who were mostly said to be unemployed who posed threat to wildlife conservation in these study areas. However, awareness on the importance of wildlife (Primates) conservation should be carried out using radio and town criers in the state to reduce the rate of ignorance on Line Transect Method.

Efforts should be made to adequately protect the study areas, through enactment of laws since they are still one of the few remaining locations in the state where some valuable tropical and indigenous tree species could be found

Keywords: Forest Reserves, Line Transect Method, Line Transect Method.

\section{INTRODUCTION}


Primates belong to the same human family, mammalidae. Most primate populations are declining and many species are critically endangered or under threat of extinction due to excessive harvesting (deforestation), (cowlishaw and dunbar, 2000, schwitzer et al, 2014).

Most of the word's primates are found in the tropic, Particularly the rainforest of lowland and ever green maintain forest of the tropical areas, with few in the savannah and other open habitats, (Richard, 1987 and Ajayi, 2015). Most hunters target primates due to their large sizes and diaunal feeding behaviours, making them more vulnerable, (Ayodele, 2009). This reason is enough to ginger any primates conservation activities. Primates belong to the first position of the animal kingdom (Ajayi 2005) including man (Homosapien), chimpanzees (Pan troglodytes), Baboons (Papio spp), just to mention a few. Researchers have found primates to be crucial in improving human health and well being (Bennett, 2015),( Joyner et al, 2015). Therefore, it has become explicitly important that primates should be jealously conserved and preserved for now and future use.

However, the survival and continuity of many endemic, rare and threatened species found in a given rangeland depend on sustainable protection/conservation through its assessment to determine their current status, (Lameed, 2010). Primate conservation in Nigeria has been loosely addressed, despite the presence of several restricted-Ranges and critically endangered primates (Oates, 2008). This has clearly been linked to poverty, population growth, urbanization, insecurity and lack of awareness among our people. Furthermore, the growing demand for essential things like space, water, food, energy and waste disposal services continually transform the landscape we occupy.

The global strategy for primate conservation, which was created by the Primate Specialist Group, (PSG) in 1978, stated that some of the strategies include protecting vulnerable areas, creating public awareness towards the issues and marking large Reserves dedicated to the maintenance and preservation of biodiversity, (Oates, 1992).

Nigeria have a rich primates fauna as twenty one species have been recorded (Oates, 1992). The richness is attributable to the unique diversity of its ecosystem. More also, Nigeria's primate fauna is a mix of species from forest to Savannah ecological Zones.

Nigeria's only (cercopithecus sclater) is known only to exist in the Eastern part of Nigeria; (Oates et al, 1992; Baker et al. 2019). Primates have been little studied by field biologists. Most of the primates in these study areas have/are migrating to a relatively stable ecological Zones due to excessive harvesting (hunting), urbanization, farming, insecurity, value for primate meat (bushmeat) and lack of awareness for primate conservation by the local indigenes.

Therefore, the main objectives of this study focused on primates survey in two selected Forest Reserves in Benue State,Nigeria. Specifically, the research include species distribution, abundance and anthropogenic activities occurring in the study locations.

This research was carried out in Yaaiwa Forest Resrve in Kwande, and Ipinu-Igede Forest Reserve in Oju local Government areas of Benue State, Nigeria. These areas were selected purposively because of some indicating factors showing the presence of primates in these natural 
forests as per oral history, foot print, faecal droppings and physical sighting by the members of the surrounding communities that settled near these Reserves.

\section{MATERIAL AND METHODS}

\subsection{The Study Area}

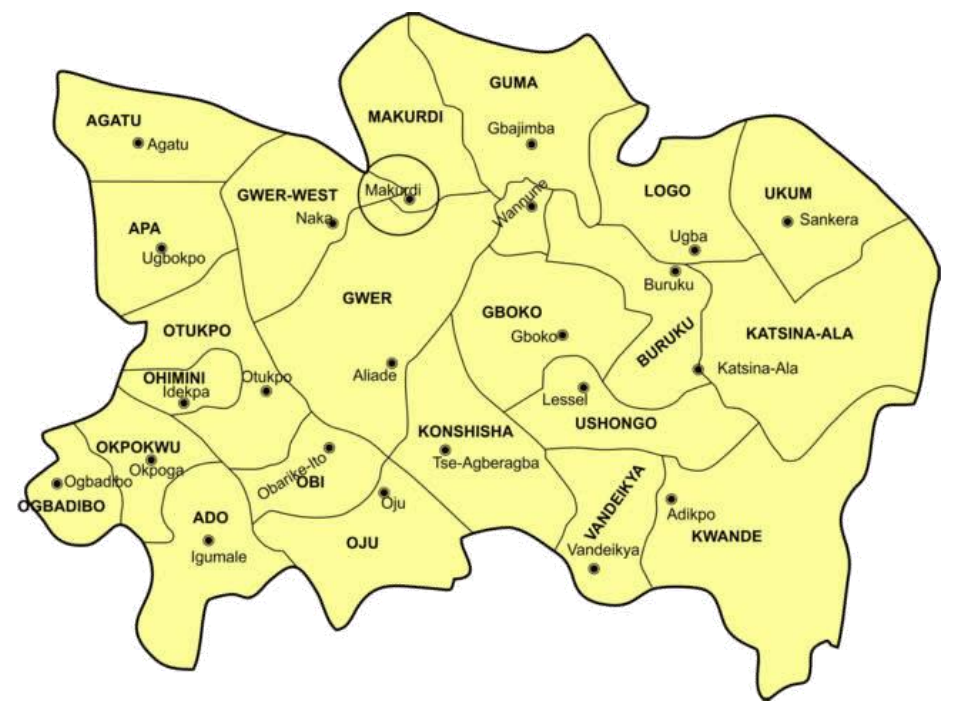

Figure 1: Map of Benue state showing locations of the study areas.

Source: Data: image/jpeg; base64, /9j/4AA. Retrieved on the 10th/06/2018.

The study was carried out in Yaaiwa Forest Reserve situated in kwande, North Eastern part of Benue State and Ipinu-Igede Forest Reserve situated in Oju local government area in southern part of Benue state, Nigeria.

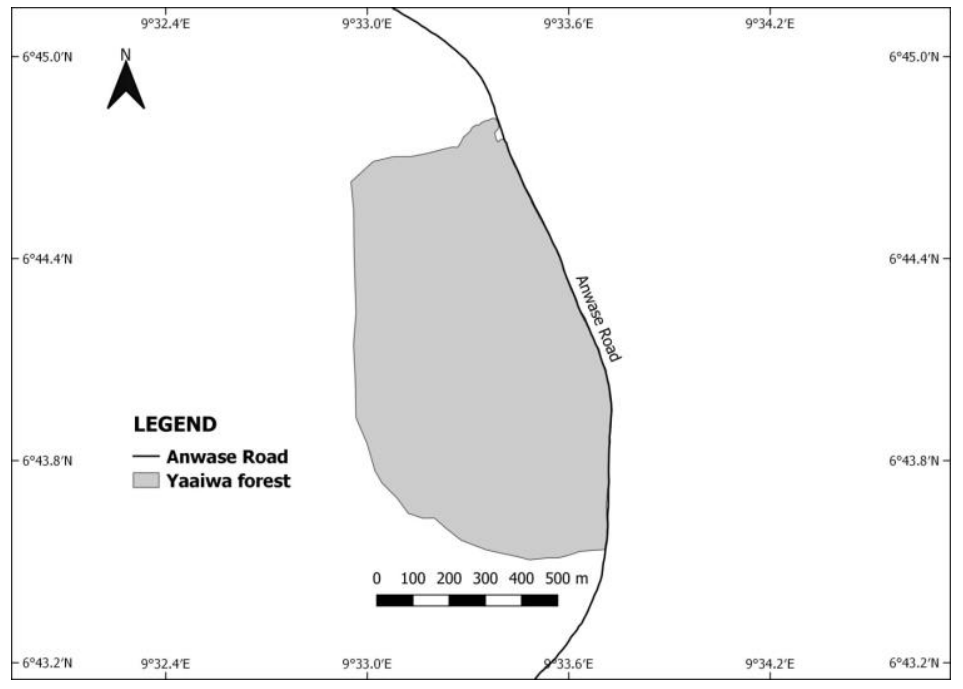


Figure 2:The map of Yaaiwa Forest Reserve

Source: Field survey, 2018.

Yaaiwa Forest Reserve is situated in Yaaiwa community of Kwande local government area North Eastern part of Benue state, Nigeria.with an elevation of $228 \mathrm{~m}$ (metres) above sea-level. Its geographical coordinates are between latitude $6^{\circ} 45^{\prime} 0 " \mathrm{Nand} 6^{\circ} 43^{\prime} 2^{\prime \prime} \mathrm{N}$. And longitude $9^{\circ} 32^{\prime}$ $4 " \mathrm{E}$ and $9^{\circ} 34^{\prime} 2^{\prime \prime E}$. Yaaiwa Forest covered an area of about $10 \mathrm{~km}^{2}$. It's bordered by several other communities such as, on the west, it is bordered by Anwase, Achia, on the northwest by Jato aka, Tomataan, Nyihemba and Torhilekia. On the south, it is bordered by Cross River State and South East, by the Republic of Cameroon.

Ipinu Igede community forest is located in Oju Local Government Area southern part of Benue State. Covering an area of approximately $4 \llbracket \mathrm{km} \rrbracket \wedge 2$ which lies within Latitude $6^{\circ} 48^{\prime} 22^{\prime \prime} \mathrm{N}$ and $6^{\circ} 48^{\prime} 12 " \mathrm{~N}$. And longitude 8० 26' 22"E and 8॰26' 94"E.

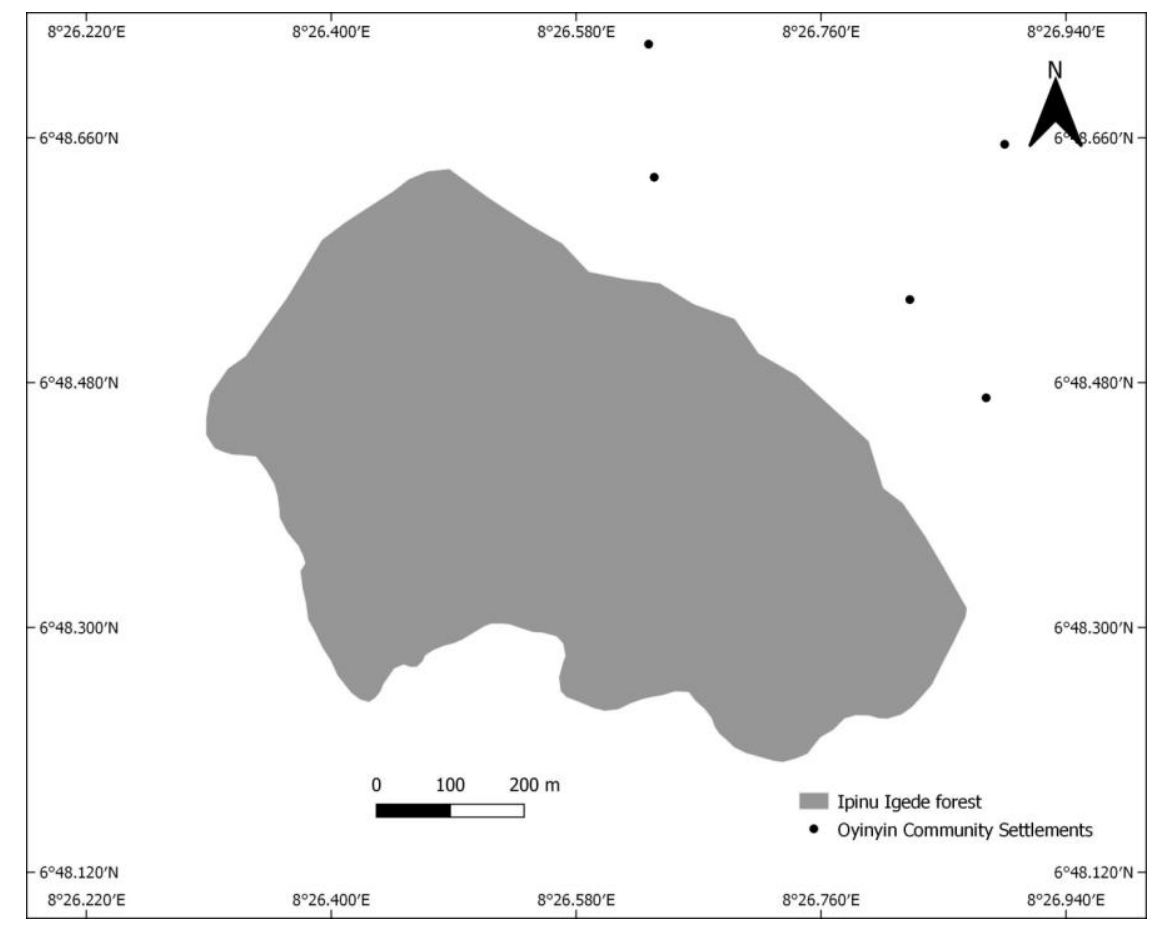

Figure 3: Map of Ipinu-igede Forest Reserve.

Source: field survey,(2018).

\section{TOPOGRAPHY/VEGETATION OF THE STUDY AREA:}

Yariwa is located at an elevation of 228 meters above sea level while that of Ipinu-Igede Forest Reserve is at an elevation of 173 meters above sea level (Benue State ministry of lands and Survey,Makurdi). These areas are located within the guinea Savannah belt which is also the broadest vegetation Zone in Nigeria. It is characterized by heterogenous species of scattered trees 
and grasses ( Nyala, 1995) such as Khaya Senegalensis (Mahogany) found mostly along stream courses. Also, commonly found in these study areas are Daniella Oliveri, Isoberlina Doka, Park in biglobosa (locust bean tree), Prosopis africana (Iron tree), Vitellaria paradoxa (shea butter tree) and Burkea africana (oil bean tree).

\section{CLIMATE}

Based on Koppen's Scheme of classification, Yaaiwa and Ipinu-Igede Forest Reserves are within the AW OR AS which is Tropical Wet and dry or Savannah climate with two distinct seasons (Wet from June to October and Dry from November to May)

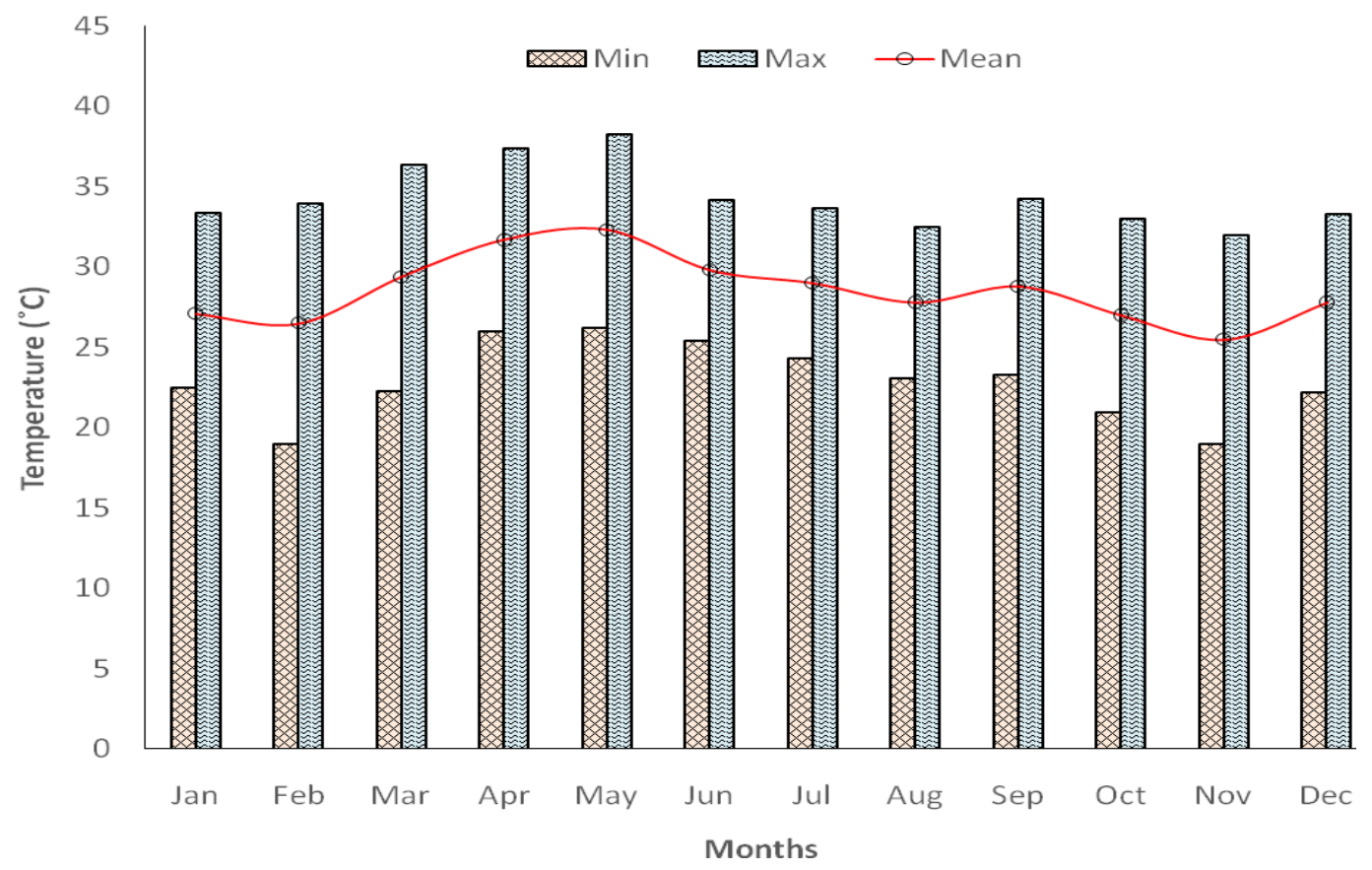

Figure 4: Bar chart of mean, minimum and maximum Temperatures of Yaaiwa Forest Reserve( 2016-2018)

Source: Lower Benue meteorological station Katsina/Ala,Benue State,Nigeria.

From figure four (4), the mean monthly( twelve months) in the year $2016-2018$, of Yaaiwa Forest Reserve showed that, the month of May had the highest temperature maximum of $38.3^{\circ} \mathrm{c}$, followed by April with the maximum temperature of $37.4^{\circ} \mathrm{c}$. February and November had the least temperatures, minimum of $19^{\circ} \mathrm{c}$. 


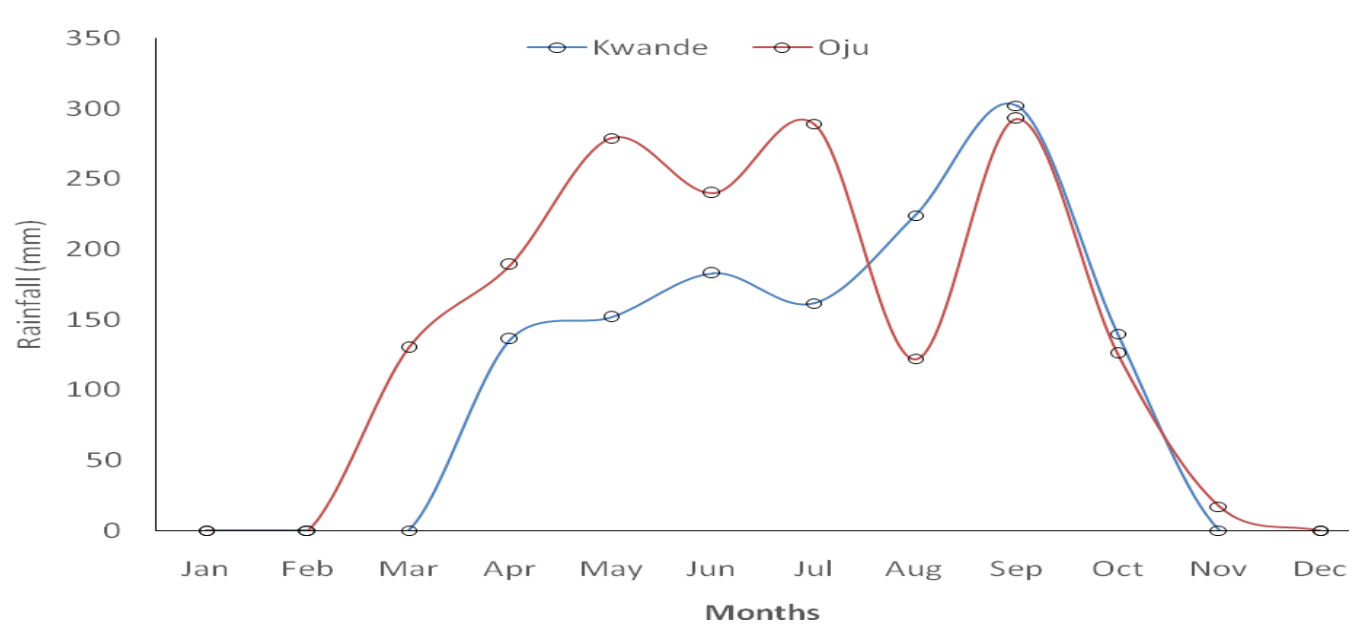

Figure 5:Total Mean Rrainfall data of Yaaiwa and Ipinu-Igede Forest Reserves (2016-2018)

Source: Lower Benue meteorological station, katsina/Ala,Benue State,Nigeria.

Figure 5, showed the Mean monthly trend of( 2016 -2018) Rainfall in Yariwa and Ipinu-igede Forest Reserves. It was observed that rain started falling in Yariwa Forest Reserve in March. The month of April had a total rainfall of $(136 \mathrm{~mm})$, then a gradual rise in the month of May $(151.7 \mathrm{~mm})$ and June $(183 \mathrm{~mm})$ with a slight drop in July $(161.7 \mathrm{~mm})$.

The rain rose again to $(224 \mathrm{~mm})$ in August and reached it picks in September $(302 \mathrm{~mm})$ and dropped to $(140 \mathrm{~mm})$ in October and stopped in November. Whereas in Ipinu-igede Forest Reserve rain started falling in February and continue rising through March (130mm), April $(189 \mathrm{~mm})$ and May $(279 \mathrm{~mm})$. It dropped a little in June $(240 \mathrm{~mm})$ and rose slightly in $\operatorname{July}(289 \mathrm{~mm})$ and a drastic drop in August $(122 \mathrm{~mm})$. It rose to its pick in September $(293 \mathrm{~mm})$.and dropped in October $(126 \mathrm{~mm})$ andNovember $(17 \mathrm{~mm})$ and finally stopped in December.

\section{METHODOLOGY}

Primate species abundance and diversity were determined by both direct and indirect observations including using long Transects of $2 \mathrm{~km}$ long. The distance between one transect line to another was 50m apart and observation was at random as described by Osunsina et al, (2012). This was in addition to household structured questionnaire, (HQS) to Respondents in the communities around the study areas.

\section{METHODS FOR SAMPLING PRIMATES POPULATION:}

The sampling technique that was used for the population of primates was the line transect method as described by Peres (1999) and used by Basuta et al (2003); Ogogo et al (2010) and Ajayi et al (2011). The data collection was done in three phases:

Phase 1: Reconnaissance survey: This was carried out between 17th - 27th January, 2018. During this period, all members of the survey team were involved in the selected and marking of 
transects. As a result of the rugged terraim which makes observation difficult, transects were selected from existing hunters' trails and farm roads, (Bassey, 2012). In selection and marking transects, the guidelines provided by Peres (1999) were followed. If an obstacle during field work, was observed, the compass man should divert the transect line, to create and offset and resume again at same bearing on the other side of the obstacle. Transect lengths of $2 \mathrm{~km}$ long and $50 \mathrm{~m}$ equal width was marked out using marking tapes and Ribbon.

Phase 2: First census (Morning 6:00am - 9:00am). This was necessary as the primates were moving out in search for food.

This involves an individual observer walking the transect with a binocular/camera for sighting with a research data sheet for recording observations. These were done simultaneously in all the five (5) selected transects using the recruited field assistances. The individuals started at one end of transects and walk at a reasonable speed of $1 \mathrm{~km} / \mathrm{hr}$ following the guides of Hacher, (2003).

Phase 3: Second census (Evening 3:00pm - 6:00pm) daily. The process was repeated each month for twelve (12) months. This was done to enable comparison of the primates population densities of the two censured areas.

Each transect was covered by an observer and the census was done simultaneously in all the five (5) selected transects. The observers were linked by means of an electronic stop watch which each possessed and this was done to reduce the incidence of double counting of primates. Fifteen field assistance were recruited, made up of 10 field Technologists, 3 Students and two Secondary School teachers. During the field census, the observers were equipped with binoculars, digital cameras, and a field data sheet to record the following informations.

1. Transect numbers

2. Right angle distance (to the path of observation) walked by observer

3. Distance of observer to animals, sighted

4. Number of animals sighted.

From the above information, the population density of primates was determined according to (Ogar (2009) method as shown below.

$\mathrm{D}=\mathrm{N} \quad$ whereby $\quad \mathrm{D}=$ Animal population density $(\mathrm{Number} / \mathrm{km} 2)$

$2 \mathrm{~L}$

$\mathrm{N}=$ Number of animal sighted.

$\mathrm{L}=$ Distance walked by observer $(\mathrm{km})$. 
Vol. 5, No. 03; 2020

ISSN: $2456-8643$

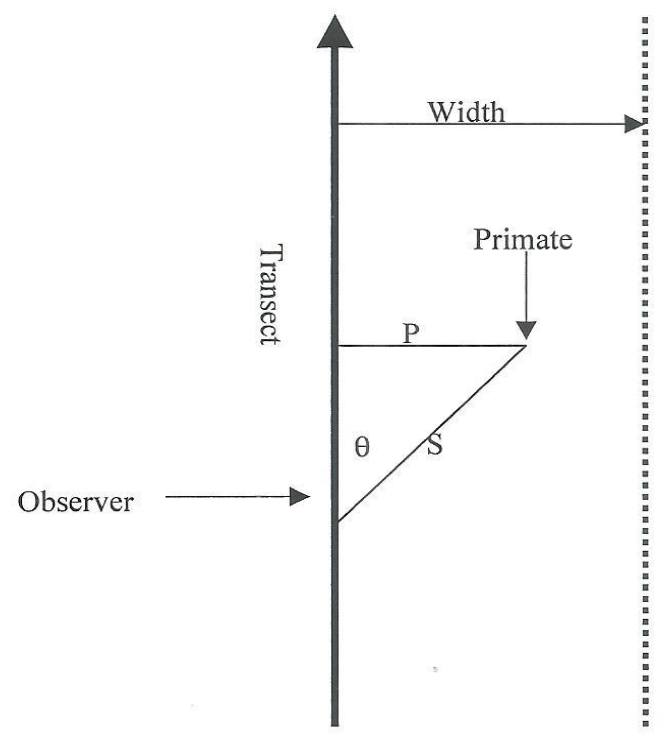

Figure 6: Line Transect Diagram.

Source: Lacher, 2003.

\section{METHODS FOR SAMPLING PLANTS POPULATIONS IN THE RESERVES:}

The Total Enumeration count Method (T.E.C) was used for the vegetation sampling data collection during the population estimate. This method was also used by Wirkikfea et al (2008) in Okomu National Park. The method involves the total enumeration of all trees plants above one meter height, and diameter of not less than $10 \mathrm{~cm}$, ( from $25 \times 25 \mathrm{~m} 2$ ). Four (4) out of the 16 quadrants were randomly selected through balloting in each of the five sampling transect giving a total of twenty (20) plots dimension of $25 \times 25 \mathrm{~m} 2$.

The following data were collected within each sampling quadrant: total counting of all tree plants above $1 \mathrm{~m}$ height and diameter $=10$; total enumeration of all the tree plant species and family to which they belong; the diameter at breast height $(\mathrm{DBH})$ of all the tree plants above $1 \mathrm{~m}$ height, i.e $(\geq 10 \mathrm{~cm})$.

The data obtained were analysed as follows;

Plant Density (Per hectare) $=$ Total number of trees counted $\mathrm{x} 1$ ha

Total Area Sampled

The Basal Area (BA) for each tree was calculated using the expression:

$$
\mathrm{BA}=)(\mathrm{D} 2
$$


Where $\mathrm{D}=$ mean diameter at breast height $(\mathrm{cm}), \mathrm{BA}=$ Basal Area $(\mathrm{m} 2)$ while the Basal Area for each plot was expressed as: $\mathrm{BAP}=\sum \mathrm{BA}$

Where BAP = Basal Area Per plot

$\sum \mathrm{BA}=$ Summation of basal areas of all trees above $1 \mathrm{~m}$ height within sampled plots.

\section{QUESTIONAIRE DISTRIBUTION:}

Two locations, Yaaiwa and Ipinu-Igede Forest Reserves in Kwande and Oju local Government Areas respectively were sampled. These study areas are surrounded by communities. Yaaiwa Forest Reserve was surrounded by Achia, Mbakoso, Kanshinbira, Yaaiwa, Anwase, Dzeve, Mbaper, Mbakya, Ikyogen and Yihemba while Ipinu-Igede Forest Reserve was surrounded by Anem-Adam, Oyinyi, Andibilla, Uchenyim, Odaleko, Ogbudo, Ikachi and Obegede-oho-oborun.

Purposive sampling method as also described by Emaikwu (2011) was used to select surrounding communities. In this method, the surrounding communities were group into two strata of A and B. A for those communities very closed to the Forest Reserve and B for those communities reasonably distanced away from the Forest Reserve.

Four communities were purposively selected, Oyinyi $(0.2 \mathrm{~km})$ and Andioilla $\left(1 \frac{1}{2} \mathrm{~km}\right)$ from the forest reserve. The purposive sampling method as described also by Emaikwu (2011) was used to distribute the eighty (80) close ended questionaire to hunters, loggers, farmers and elderly persons in those communities because of their experience. Focus group discussion (FGD) as well as in-depth interview (IDI) were requested from community leaders.

Descriptive statistic tools such as bar-charts, pie-charts and pictograms were used to analyse the data on: Anthropogenic activities and demographic socia-economic assessment of the surrounding communities of the Reserves.

The students T-test (Test of independent means) was used to compare the result obtained from the two censured areas of primates population densities using the following hypothesis.

H0: There is no significance difference in the mean densities of primates in the two censured areas.

H1: There is significant difference in the means densities of primates in the two censured areas.

The test criterion is given as;

$\mathrm{t}=1 \mathrm{x} 1-\mathrm{x} 21$

$\mathrm{x} 1=$ means density of first census.

$\mathrm{x} 2=$ means density of second census

$\mathrm{sp}=$ pooled variance 
$\mathrm{n} 1=$ frequency of sight for first census

$\mathrm{n} 2=$ frequency of sight for second census

The data analysed were presented in tables, charts and figures

Table 1: Diversity Indices of Primates in Yariwa and Ipinu-Igede Forest Reserves

\begin{tabular}{|lll|}
\hline Diversity Indices & Forest Reserves & \\
\hline & Ipinu-Igede & Yaaiwa \\
\hline Individuals & 149 & 105 \\
Dominance D & 0.031 & 0.038 \\
Simpson 1-D & 0.968 & 0.961 \\
Shannon H & 3.509 & 3.299 \\
Evenness e^H/S & 0.954 & 0.967 \\
Margalef & 6.795 & 5.802 \\
Fisher Alpha & 14.420 & 12.490 \\
Berger Parker & 0.053 & 0.057 \\
\hline
\end{tabular}

Source: Field survey, (2018).

From table 1, the result showed that, of the twelve (12) months of survey in Yaaiwa and Ipinuigede Forest Reserves a total of one hundred and forty nine (149) primate's species were sighted in Ipinu-igede Forest Reserve whereas one hundred and five were observed in Yariwa Forest Reserve. Species dominance varies from 0.03/km in Ipinu-Igede Forest Reserve to $0.04 / \mathrm{km}$ in Yaaiwa Forest Reserve. Simpson's index ranges from 0.97 in Ipinu-Igeded Forest Reserve to 0.96 in Yaaiwa Forest Reserve. Shannon wiener diversity index ranges from 3.51 in Ipinu-Igede Forest Reseerve to 3.21 in Yaaiwa Forest Reserve. Margalef's richness index falls between 6.71 in Ipinu-Igede Forest Reserve to 5.80 in Yaaiwa Forest Reserve..The Fisher Alpha index ranges from 14.42 in Ipinu-Igede Forest Reserve to 12.49 in Yaaiwa Forest Reserve and the Berger parker index falls between 0.05 in Ipinu-Igede Forest Reserve to 0.06 in Yaaiwa Forest Reserve.

From the results it was observed that no variations of species diversity exist between the two Forest Reserves. It also observed that there is no significant difference at 5\% level of significance. The Shannon-Weiner diversity index usually varies from 1.5 to 3.5 and rarely exceeds 4.5 (Kent \& Coker 1992). A low H value generally suggests a site with few species and a few dominant species, while a high $\mathrm{H}$ value suggests considerably more species. This study observed a high Shannon-Weiner diversity index of 3.51 in Ipinu-igede Forest Reserve and 3.21 
in Yaaiwa Forest Reserve. This suggests that both Yaaiwa and Ipinu-igede forest reserves had considerably species.

Table 2: Diversity Indices of Primates by Season in Yaaiwa and Ipinu-Igede Forest Reserves Diversity Indices

\begin{tabular}{|lll|}
\hline Diversity Indices & \multicolumn{2}{c|}{ Season } \\
\hline & Dry & Wet \\
\hline Individuals & 68 & 186 \\
Dominance D & 0.048 & 0.025 \\
Simpson 1-D & 0.951 & 0.974 \\
Shannon H & 3.031 & 3.698 \\
Evenness e^H/S & 0.986 & 0.960 \\
Margalef & 4.740 & 7.846 \\
Fisher Alpha & 10.390 & 16.900 \\
Berger Parker & 0.058 & 0.043 \\
\hline
\end{tabular}

The result observed in dry season showed that, the total number of primate species encountered in dry season was 68 whereas 186 were observed in the wet/rainy season. Lack of feeds, water, open vegetation or hunting pressure in dry season could be the possible reason why the animals were not sighted easily in during this period.

For the wet/rainy season, this may be as a result of fruits and water available in the season which triggers the animals to come out of their hide. Species Dominance ranges from 0.05 in dry season to 0.03 in rainy/wet season. Simpson index falls between 0.95 in dry season to 0.97 in wet season. The Shannon-Weiner diversity index usually varies from 3.03 in dry season to 3.61 in the rainy/wet season. The degree of Evenness was 0.99 in dry season and 0.96 in the wet season. Margalef species richness varies from 4.74 in dry season to 7.85 in the rainy/wet season. Fisher Alpha value from 10.39 in dry season to 16.90 in wet season. Berger Parker ranges from 0.06 in dry season to 0.04 in wet season.

The Shannon-Weiner diversity index usually varies from 1.5 to 3.5 and rarely exceeds 4.5 . A low $\mathrm{H}$ value generally suggested a site with few species and a few dominant species, while a high $\mathrm{H}$ value suggested considerably more species. The result observed that the wet season had a higher Shannon-Weiner H value (3.61) compared to dry season (3.03). This suggested that the 
rainy/wet season had more number of primates species sighted probably due to availability of eatable fruits.The florishing vegetation acted as protection and gave shades to these animals.

Table 3: Seasonal Percentage Abundance Of Primates Sighted In Yaaiwa And Ipinu-Igede Forest Reserves.

\begin{tabular}{|llll|}
\hline Species & Season & Wet & $\begin{array}{l}\text { Total Number } \\
\text { Sighted(ipinu- }\end{array}$ \\
\hline & Dry & $56(78.78)$ & 71 \\
igede+yaaiwa)
\end{tabular}

Source: Field survey, (2018).

Based on the seasonal result obtained in the two Forest Reserves, for a period of twelve (12) months of survey, only three (3) species of primates were sighted in both Forest Reserves. Among the three (3) species Patas monkey (Erythrocebus patas) has the highest number with One hundred and thirty six (136) in dry season and one hundred and one (101) in the rainy/wet season. This was followed by olive Baboon (Papio anubis) with seventy one (71) in dry season and fifty six (56) in the wet/rainy season. Tantalus monkey (chlorocebus aethiops) had the least number of forty six (46) in dry season and twenty nine (29) in rainy/wet season

Table 4:Mean Seasonal Density Of Primates' Species Sighted Per $\mathrm{Km}^{2}$ In Yaaiwa And Ipinu-Igede Forest Reserves.

\begin{tabular}{|llllll|}
\hline Species & Season & & Df & T- & P- \\
\hline & Dry & Wet & & Value & Value \\
\hline Olive Baboon & $0.016 \pm 0.004$ & $1.680 \pm 0.130$ & 14 & 1.47 & 0.16 \\
Patas Monkey & $0.010 \pm 0.002$ & $0.019 \pm 0.005$ & 26 & 1.54 & 0.13 \\
Tantalus Monkey & $0.014 \pm 0.003$ & $0.007 \pm 0.001$ & 6 & 1.75 & 0.13 \\
\hline
\end{tabular}

Source: Field survey, (2018).

The seasonal density of primates species sighted in the two Forest Reserves as indicated in table 4. Showed that, the population density of olive Baboon (Papio anubis) in the dry season was $0.02 / \mathrm{km}^{2}$ and $1.68 / \mathrm{km}^{2}$ in the rainy/wet season respectively. And Patas monkey (Erythrocebus patas) was $0.01 / \mathrm{km}^{2}$ in dry season and $0.019 / \mathrm{km}^{2}$ in rainy season. Tantalus monkey (chlorocebus aethiops) had $0.01 / \mathrm{km}^{2}$ in dry season and $0.01 / \mathrm{km}^{2}$ in wet season. Both dry and wet season were 
not significantly different as p- values of 0.16 and 0.13 are greater than alpha value of 0.05 respectively.

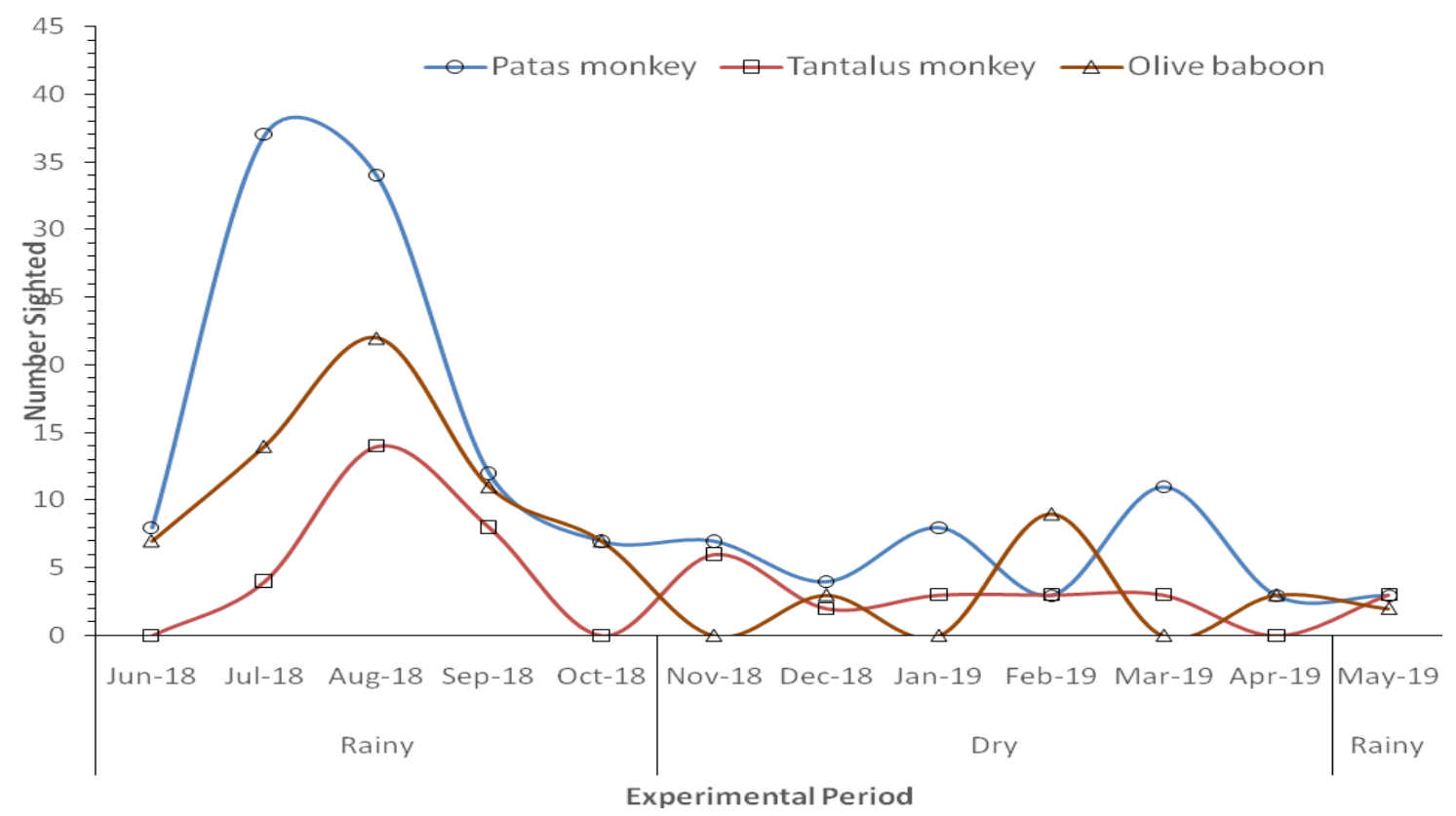

Figure 7: Monthly Trend in Number of Primates species Sighted in dry and wet season in the study areas.

Source: Field survey, (2018).

Figure7, indicated the monthly trend of primates by season in both Yaaiwa and ipinu-igede Forest Reserves. Patas monkey (Erythrocebus patas) had the highest number of sightings, followed by Olive baboon (Papio anubis). Tantalus monkey (chlorocebus aethiops) has the least number. The species were sighted more during the wet season between June to September (2018). The population dropped drastically from October (2018) to January (2019) and raised a little from February to April, (2019). This could be as a result of their edible fruits availability in the wet season than in the dry season. 


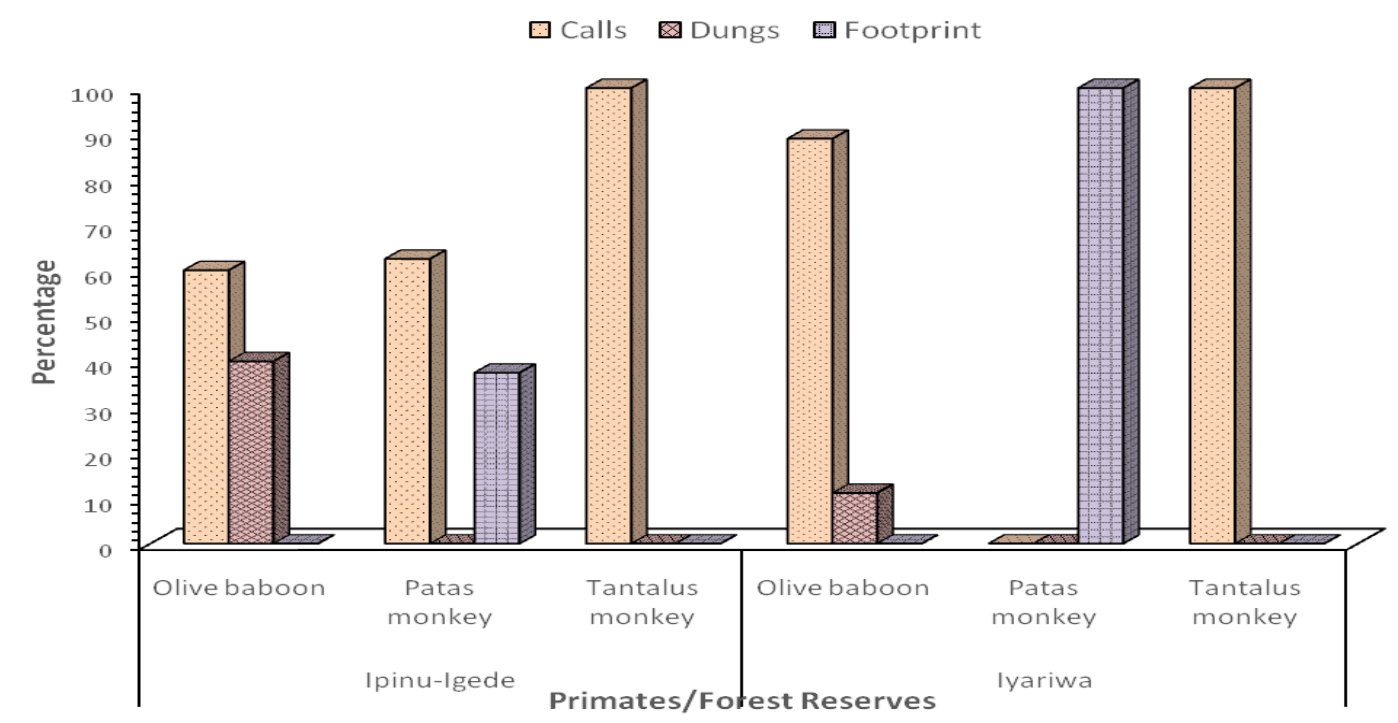

Figure 8: A bar chart showing Indirect indices of primates' species encountered in Ipinu-igede and Yaaiwa Forest Reserves.

Source: Field survey, (2018).

As shown in figure 8 above, three indirect indices calls, Dungs and foot prints of primates were encountered in the study areas. Calls were encountered more in both Forest Reserves, followed by foot prints. Dungs had the least encounter rate in the two Forest Reserves.

Table 5: Stocking and Tree Species Diversity Indices in Yaaiwa Forest Reserve.

\begin{tabular}{|l|l|l|}
\hline S/No & Parameters & Values \\
\hline 1 & Number of species & 23 \\
2 & Number of trees & 559 \\
3 & Total Sample Area (ha) & 12.5 \\
4 & Number of trees/ha & 45 \\
5 & Basal area (m $\left.{ }^{2} / \mathrm{ha}\right)$ & 25.39 \\
6 & Shannon-wiener & 2.432 \\
7 & Pielou Evenness & 0.776 \\
8 & Margalef Index & 3.478 \\
\hline
\end{tabular}

Source: Filed survey, (2018) 
From table 5, the result showed that twenty three (23) different species of trees were encountered in the sampled area of Yaaiwa Forest Reserve. A total of five hundred and fifty nine (559) trees were counted and the area sampled was 12.5 hectaresas as forty five (45) trees were counted per hectare. With Shannon-weiner diversity index of 2.43.Shannon-Weiner diversity index usually varies from 1.5 to 3.5 and rarely exceeds 4.5 (Kent \& Coker 1992). A low H value generally suggests a site with few species and a few dominant species, while a high $\mathrm{H}$ value suggests considerably more species. The result obtained from Yaaiwa Forest Reserve has a low $\mathrm{H}$ value of 2.43 which agrees with kent and coker (1992) Suggesting that Yaaiwa Forest Reserve is a site with few species and a few dominant species. Pielou Evenness ranges between 0.78 and Margalef index between 3.48 in Yaaiwa Forest Reserve

Table 6: Stocking and Tree Species Diversity Indices in Ipinu-Igede Forest Reserv.

\begin{tabular}{|lll|}
\hline S/No & Parameters & Values \\
\hline 1. & Number of species & 26 \\
2. & Number of trees & 447 \\
3. & Total Sample Area (ha) & 12.5 \\
4. & Number of trees/ha & 36 \\
5. & Basal area $\left(\mathrm{m}^{2} / \mathrm{ha}\right)$ & 32.37 \\
6. & Shannon-wiener & 2.375 \\
7. & Pielou Evenness & 0.729 \\
8. & Margalef Index & 4.097 \\
\hline
\end{tabular}

Source: Filed survey,(2018)

From table 6, there were twenty six (26) different species of trees, total number of trees in the sampled area was four hundred and forty seven (447), total area sampled was 12.5 hectares and the number of trees per hectare was 36/ha. The Shannon-Weiner diversity index usually varies from 1.5 to 3.5 and rarely exceeds 4.5 (Kent \& Coker 1992). A low H value generally suggests a site with few species and a few dominant species, while a high $H$ value suggests considerably more species. The result obtained from ipinu-igede Forest Reserve has a low $\mathrm{H}$ value of 2.38 which agrees with kent and coker (1992) Suggesting that ipinu-igede Forest Reserve is a site with few species and dominant species. Pielou Evenness ranges between 0.73 and Margalef Index falls between 4.01 in Ipinu-Igede Forest Reserve. 
Table 7: Socio-Economic Characteristics of Respondents in Yaaiwa and Ipinu-Igede Forest Reserves.

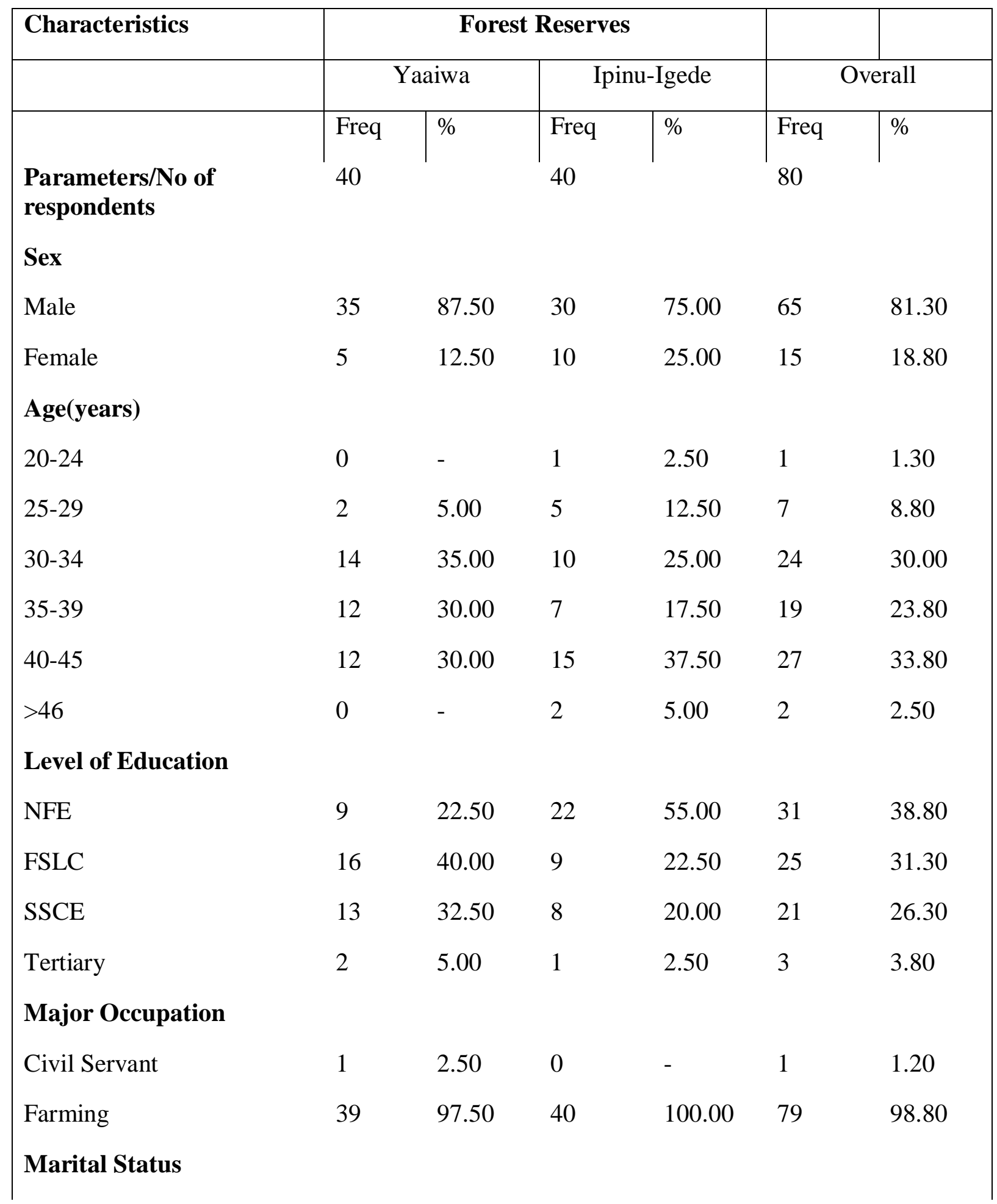


Vol. 5, No. 03; 2020

ISSN: $2456-8643$

\begin{tabular}{|lllllll|}
\hline Married & 40 & 100.00 & 39 & 97.50 & 79 & 98.80 \\
Unmarried & 0 & - & 1 & 2.50 & 1 & 1.20 \\
Tribe & & & & & & \\
Tiv & 40 & 100.00 & 0 & - & 40 & 50.00 \\
Igede & 0 & - & 40 & 100.00 & 40 & 50.00 \\
Period of Residence (Yrs) & & & & & & \\
$1-25$ & 3 & 7.50 & 7 & 17.50 & 10 & 12.50 \\
$26-45$ & 37 & 92.50 & 30 & 75.00 & 67 & 83.80 \\
$46-65$ & 0 & - & 3 & 7.50 & 3 & 3.80 \\
Religion & & & & & & \\
Christianity & 40 & 100.00 & 40 & 100.00 & 80 & 100 \\
\hline
\end{tabular}

Source: Field survey, (2018).

Table 7 showed that, 80 respondents were administered with questionnaire in Yaaiwa and Ipinuiged Forest Reserves. Out of the eigty (80) respondents males were sixty five (65) (81.3\%) i.e thirty five(35) $(87.5 \%)$ in yaaiwa and thirty (30) $(75 \%)$ in ipinu-igede. Females were fifteen (15) $(18.8 \%)$ i.e five (5) (12.5\%) in yariwa and 10 (25\%) in ipinu-igede.

Table 8: Awareness of Prohibitions of Hunting Activities in Yaaiwa and Ipinu-Igede Forest Reserve.

\begin{tabular}{|c|c|c|c|c|c|c|}
\hline \multirow[t]{3}{*}{ Characteristics } & \multicolumn{4}{|c|}{ Forest Reserves } & & \\
\hline & \multicolumn{2}{|c|}{ Yaaiwa } & \multicolumn{2}{|c|}{ Ipinu-Igede } & \multicolumn{2}{|c|}{ Overall } \\
\hline & Freq & $\%$ & Freq & $\%$ & Freq & $\%$ \\
\hline $\begin{array}{l}\text { Parameters/No of } \\
\text { respondents }\end{array}$ & 40 & & 40 & & 80 & \\
\hline \multicolumn{7}{|c|}{ Participation in hunting } \\
\hline Yes & 0 & - & 7 & 17.50 & 7 & 8.80 \\
\hline No & 40 & 100.00 & 33 & 82.50 & 73 & 91.20 \\
\hline
\end{tabular}


Vol. 5, No. 03; 2020

ISSN: $2456-8643$

\begin{tabular}{|c|c|c|c|c|c|c|}
\hline $1-5$ & 0 & - & 1 & 2.50 & 1 & 1.30 \\
\hline $6-10$ & 0 & - & 2 & 5.00 & 2 & 2.50 \\
\hline $11-15$ & 0 & - & 2 & 5.00 & 2 & 2.50 \\
\hline $16-20$ & 0 & - & 0 & - & 0 & - \\
\hline$>20$ & 0 & - & 2 & 5.00 & 2 & 2.50 \\
\hline \multicolumn{7}{|l|}{ Weapons used } \\
\hline Wire snares & 0 & - & 1 & 2.50 & 1 & 1.30 \\
\hline Dane gun & 0 & - & 3 & 7.50 & 3 & 2.50 \\
\hline Short gun & 0 & - & 3 & 7.50 & 3 & 2.50 \\
\hline \multicolumn{7}{|c|}{$\begin{array}{l}\text { Primates encountered } \\
\text { during hunting }\end{array}$} \\
\hline Olive baboon & 0 & - & 1 & 2.50 & 1 & 1.30 \\
\hline Patas monkey & 0 & - & 1 & 2.50 & 1 & 1.30 \\
\hline Tantalus monkey & 0 & - & 5 & 12.50 & 5 & 6.30 \\
\hline \multicolumn{7}{|c|}{$\begin{array}{l}\text { Hunting effects on } \\
\text { primate population }\end{array}$} \\
\hline Increase & 0 & - & 0 & - & 0 & - \\
\hline Decrease & 0 & - & 7 & 17.50 & 7 & 8.80 \\
\hline \multicolumn{7}{|c|}{$\begin{array}{l}\text { Awaereness of prohibition } \\
\text { of killing primates }\end{array}$} \\
\hline Yes & 7 & 17.50 & 0 & - & 7 & 8.80 \\
\hline No & 33 & 82.50 & 40 & 100.00 & 73 & 91.20 \\
\hline \multicolumn{7}{|c|}{ Source of awareness } \\
\hline Radio & 7 & 17.50 & 0 & - & 7 & 8.80 \\
\hline
\end{tabular}

Source: Field survey, (2018).

From table 8 above, of the eighty (80) respondents, seven (7) (8.8\%) of them were observed to had participated in hunting in Ipinu-igede Forest Reserve. However one (1) (1.3\%) of them have 
being hunting over a period of 1-5 years, two (2) (2.5\%) agreed to had being hunting over 6-10 years, two (2) (2.5\%) also agreed to had being hunting over a period of 11-15 years and two (2) $(2.5 \%)$ have being hunting over a period of 20 years and above.

Two (2) (2.5\%) of these hunters indicated that they used wire-snares in hunting. Three (3) (3.8\%) of them agreed to have used Dane gun, another three (3) (3.8\%) indicated to had used shot gun. Seven of them indicated to have encountered some primates' species during hunting. Of the seven (7), One (1) (1.3\%) respondent agreed to have encountered Olive baboon (Papio anubis). One (1) (1.3\%) was observed to had encountered Patas monkey (Erythrocebus patas) and five (5) $(6.3 \%)$ indicated to have encountered Tantalus monkey (chlorocebus aethiops). they were all of the view that the population of primates in these Forest Reserves were decreasing.

Their awareness on the law prohibiting the killing of primates' species in and around these Reserves showed that, only seven (7) (8.8\%) respondents were aware of the law. All the seven (7) $(8.8 \%)$ respondents got their source of awareness via Radio. Whereas seventy three (73) $(91.2 \%)$ were observed not to be aware of the law prohibiting the killing of primates.

Table 9: Awareness of Prohibitions of Logging Activities in Yaaiwa and Ipinu-Igede Forest Reserves.

\begin{tabular}{|c|c|c|c|c|c|c|}
\hline \multirow[t]{3}{*}{ Characteristics } & \multicolumn{4}{|c|}{ Forest Reserves } & & \\
\hline & \multicolumn{2}{|c|}{ Yaaiwa } & \multicolumn{2}{|c|}{ Ipinu-Igede } & \multicolumn{2}{|c|}{ Overall } \\
\hline & Freq & $\%$ & Freq & $\%$ & Freq & $\%$ \\
\hline $\begin{array}{l}\text { Parameters/No of } \\
\text { respondents }\end{array}$ & 40 & & 40 & & 80 & \\
\hline \multicolumn{7}{|c|}{ Participation in logging } \\
\hline Yes & 7 & 17.50 & 0 & - & 7 & 8.80 \\
\hline No & 33 & 82.50 & 40 & 100.00 & 73 & 91.20 \\
\hline \multicolumn{7}{|l|}{ Years in logging } \\
\hline $1-5$ & 7 & 17.50 & 0 & - & 7 & 8.80 \\
\hline \multicolumn{7}{|c|}{$\begin{array}{l}\text { Primates encountered } \\
\text { during logging }\end{array}$} \\
\hline Olive baboon & 4 & 10.00 & 0 & - & 4 & 5.00 \\
\hline Tantalus monkey & 3 & 7.50 & 0 & - & 3 & 3.80 \\
\hline
\end{tabular}


Vol. 5, No. 03; 2020

ISSN: $2456-8643$

\begin{tabular}{|lllllll|}
\hline Increase & 0 & - & 0 & - & 0 & - \\
Decrease & 7 & 17.50 & 0 & - & 7 & 8.80 \\
$\begin{array}{l}\text { Awaereness of prohibition } \\
\text { of logging in Forest } \\
\text { Reserves }\end{array}$ & & & & & & \\
Yes & 7 & 17.50 & 0 & - & 7 & 8.80 \\
No & 33 & 82.50 & 40 & 100.00 & 73 & 91.20 \\
Source of awareness & & & & & & \\
Radio & 7 & 17.50 & 0 & - & 7 & 8.80 \\
\hline
\end{tabular}

Source: Field survey, (2018).

From table 9, eighty (80) respondents were administered with questionnaire, of the eighty (80), only seven (7) (8.8\%) agreed to had participated in logging and it was observed they have been logging over a period of 1-5 years. They also indicated that during their logging activities the encountered two different species of primates. Four (4) (5\%) were observed to had encountered Olive baboon and three (3) (3.8\%) agreed to had encountered Tantalus monkey. They also accepted the fact that the population of primate species in and around these Reserves had decrease totally. Concerning their awareness on the law prohibiting logging in and around these Forest Reserves, only seven (7) (8.8\%) of them agreed to be aware of this laws and their source of awareness was Radio. Seventy three (73) (91.2\%) of them indicated that they were not aware of the law prohibiting logging in these Reserves.

Table 10: Awareness of Respondents on the Prohibition of Farming Activities in the Forest Reserves.

\begin{tabular}{|c|c|c|c|c|c|c|}
\hline \multirow[t]{3}{*}{ Characteristics } & \multicolumn{4}{|c|}{ Forest Reserves } & & \\
\hline & \multicolumn{2}{|c|}{ Yaaiwa } & \multicolumn{2}{|c|}{ Ipinu-Igede } & \multicolumn{2}{|c|}{ Overall } \\
\hline & Freq & $\%$ & Freq & $\%$ & Freq & $\%$ \\
\hline $\begin{array}{l}\text { Parameters/No of } \\
\text { respondents }\end{array}$ & \multicolumn{2}{|l|}{40} & \multicolumn{2}{|l|}{40} & \multicolumn{2}{|l|}{80} \\
\hline \multicolumn{7}{|c|}{ Participation in farming } \\
\hline Yes & 40 & 100.00 & 40 & 100.00 & 80 & 100.00 \\
\hline No & 0 & - & 0 & - & 0 & - \\
\hline \multicolumn{7}{|l|}{ Years in Farming } \\
\hline
\end{tabular}


Vol. 5, No. 03; 2020

ISSN: $2456-8643$

\begin{tabular}{|c|c|c|c|c|c|c|}
\hline $1-5$ & 0 & - & 0 & - & 0 & - \\
\hline $6-10$ & 0 & - & 2 & 5.00 & 2 & 2.50 \\
\hline $11-15$ & 1 & 2.50 & 0 & - & 1 & 1.30 \\
\hline $16-20$ & 14 & 35.00 & 5 & 12.50 & 19 & 23.80 \\
\hline$>20$ & 25 & 62.50 & 33 & 82.50 & 58 & 72.50 \\
\hline \multicolumn{7}{|l|}{ Farming system } \\
\hline Shifting cultivation & 40 & 100.00 & 40 & 100.00 & 80 & 100.00 \\
\hline \multicolumn{7}{|c|}{$\begin{array}{l}\text { Primates encountered } \\
\text { during farming }\end{array}$} \\
\hline Olive baboon & 21 & 52.50 & 2 & 5.00 & 23 & 28.70 \\
\hline Patas monkey & 18 & 45.00 & 31 & 77.50 & 49 & 61.30 \\
\hline Tantalus monkey & 1 & 2.50 & 7 & 17.50 & 8 & 10.00 \\
\hline \multicolumn{7}{|c|}{$\begin{array}{l}\text { farming effects on primate } \\
\text { population }\end{array}$} \\
\hline Increase & 0 & - & 0 & - & 0 & - \\
\hline Decrease & 40 & 100.00 & 40 & 100.00 & 80 & 100.00 \\
\hline \multicolumn{7}{|c|}{$\begin{array}{l}\text { Awaereness of prohibition } \\
\text { of farming in Forest } \\
\text { Reserves }\end{array}$} \\
\hline Yes & 8 & 20.00 & 0 & - & 8 & 10.00 \\
\hline No & 32 & 80.00 & 40 & 100.00 & 72 & 90.00 \\
\hline \multicolumn{7}{|l|}{ Source of awareness } \\
\hline Radio & 8 & 20.00 & 0 & - & 8 & 10.00 \\
\hline
\end{tabular}

Source: Field survey, (2018).

Table 10, showed that eighty (80) respondents were administered with questionnaire in Yaaiwa and Ipinu-igede Forest Reserves and all the eighty (80) (100\%) respondents were observed to be farmers. Two (2) (2.5\%) were observed to have being farming over a period of 6-10 years. one (1) $(1.3 \%)$ was observed to have being farming over a period of 11-15 years. Nineteen (19) (23.8\%) were observed to have being farming over a period of 16-20 years. Fifty eight (58) (72.5\%) were observed to have being farming over a period of twenty years. Above all, the 
respondents indicated that they have being practicing shifting cultivation system of farming. And during their farming periods they encountered three species of primates Olive baboon, Patas monkey and Tantalus monkey. Twenty three (23) (28.7\%) of them agreed to have encountered Olive baboon, Forty nine (49) (61.3\%) were observed to have encountered Patas monkey, eight (8) $(10 \%)$ of them agreed to have encountered Tantalus monkey during farming. One hundred per cent $(100 \%)$ of the respondents in both Forest Reserves indicated that the population of primates have decreased drastically over the past ten years. Seventy two (72) (90\%) of these respondents, were not aware of the law prohibiting farming in these Reserves. Only eight (8) (10\%) were observed to be aware of the law and their source of awareness was through Radio.

\section{DISCUSSION}

\section{Assessment of Anthropogenic Activities Occurring In Yaaiwa and Ipinu-Igede Forest Reserves.}

The anthropogenic activities observed during this study were: hunting, logging and farming which are in accordance with those observed by Oladeji et.al, (2010), in Old Oyo National Park that included Hunting, logging, Grazing, Fishing, Honey Harvesting, Farming, and exploitation of Non Timber Forest Products (NTFPs).

\section{Level of Hunting, logging and farming in the Study Area.}

As indicated in table 10, the level of hunting pressure in the study areas was assessed. Eighty (80) respondents submitted their reports and only seven (7) (8.8\%) from Ipinu-igede were observed to be hunters. This level of hunters is, however lower than that observed by Ajayi et al, (2012) in Okomu National Park where (10\%) of hu

nters were found to have poached int

\section{Level of logging in the Study Areas}

From table 10, seven (7) (8.8\%) respondents were observed to had encroached in Yaaiwa Forest Reserve. This level of loggers encroachment is however, lower than that observed by Ajayi et al (2012) in Okomu National Park where (10\%) of loggers were found to have encroached into the Park. This could also be as a result of traditional laws enacted by the traditional rulers in these Forest Reserves. Believing that anyone who cut down a tree in the Reserves will die.

\section{Level of farming in the Study Areas}

As indicated in table 10 also, the level of farming in the study areas were very high (100\%). This high rate could be as a result of high level of pressure on the Forests as majority of the people living around the study areas were farmers.

This agreed with Mittermeier et al., (2009) who observed high rate of farming in communities around Pandam Wildlife Park. He observed there were over 600 illegal farms in his study area. This also agreed with the findings of Henry et al., (2012), where 92.6\% farmer encroached Kainji lake National Park 
Vol. 5, No. 03; 2020

ISSN: $2456-8643$

Awareness on the prohibition of logging, hunting and farming in the study areas (Yaaiwa and Ipinu-Igede Forest Reserves)

From table $8-10$, only $22(27.6 \%)$ admitted to be aware of the law prohibiting hunting, logging and farming in the Forest Reserves, whereas $58(72.5 \%)$ admitted that they were not aware of these anti conservation practices.

The implication here is that efforts should be intensified through workshops and more people (Stakeholders should be involved) more in conservation programs and jingles should be aired on the radio promoting wholesome conservation practices. The lack of awareness here could be as a result of not showing concern over conserved areas. This is because the 22 respondents that admitted to be aware of the law prohibiting hunting, logging and farming in these Reserves got their source of awareness through one channel (Radio).

This low level of awareness did not agree with the observation of Edet et al, (2006), who observed high level of awareness among the respondents in the enclaves of the Cross River National Park.

\section{Diversity and abundance of primate's species sighted in the study areas.}

Species diversity, to which species richness and evenness contribute to a varying degree, is the subject matter of biodiversity and conservation biology because it acts as an indicator in most ecological studies.

The Shannon-Weiner diversity index usually varies from 1.5 to 3.5 and rarely exceeds 4.5 (Kent \& Coker 1992). A low $\mathrm{H}$ value generally suggests a site with few species and a few dominant species, while a high $\mathrm{H}$ value suggests considerably presence of species.

From table 10, the result showed that out of the twelve (12) months of survey in Yaaiwa and Ipinu-igede Forest Reserves a total of one hundred and forty nine (149) primate's species were sighted in Ipinu-igede Forest Reserve, whereas one hundred and five were observed in Yaaiwa Forest Reserve. Also, it was observed that no major variations of species diversity exist between the two Forest Reserves. It was also observed that there was no significant difference at 5\% level of significance between Yaaiwa and Ipinu-Igede Forset Reserves. This study observed a high Shannon-Weiner diversity index of 3.51 in Ipinu-igede Forest Reserve and 3.29 in Yaaiwa Forest Reserve suggesting that both Yaaiwa and Ipinu-igede Forest Reserves had considerably more dominant species but no diversity as eveness equal 0.99 and 0.96 respectively.

\section{Primate species availability and distribution in the study areas}

The result obtained in the two Forest Reserves as shown in table $9 \& 10$, for a period of twelve (12) months of survey, only three (3) species of primates were sighted in Yaaiwa and Ipinu-Igede Forest Reserves. Among the three (3) species Patas monkey (Erythrocebus patas) has the highest number of One hundred and thirty seven with thirty six (36) in dry season and one hundred and one (101) in rainy/wet season. 
This was followed by olive Baboon (Papio anubis), seventy one (71) with fifteen (15) in dry season and fifty six (56) in wet/rainy season. Tantalus monkey (Chlorocebus aethiops) had the least number, forty six (46) with Seventeen (17) in dry season and twenty nine (29) in rainy/wet season. This variation could be as a result of fruits, blossom trees composition and water availability during the rainy/wet season that made the animals comfortable.

\section{CONCLUSION}

A survey of primates in two selected Forest Reserves in Benue state was carried out in Yaaiwa Forest Reserve in Kwande Local government area and Ipinu-igede Forest Reserve in Oju Local government area of Benue state, Nigeria respectively, between the months of June 2018 toMay 2019. Three (3) species of primates: Olive baboon (Papio anubis), Patas monkey (Erythrocebus patas) and Tantalus monkey (Chlorocebus aethiops) were sighted in both Yaaiwa and IpinuIgede Forest Reserves. The population density of the three species of primates sighted in the study areas was very low, $0.02 / \mathrm{Km} 2$ in dry season and $1.68 / \mathrm{Km} 2$ in rainy/wet season. Also observed were high rate of anthropogenic activities of Farming, Hunting and logging in and around the study areas. The tree species and ecology of the study areas were mainly of primary forest though seriously modified through human activities. The increased in farmer's population and urbanization in these study areas posed a serious threat to the conservation of primates.

\section{RECOMMENDATIONS}

Based on the above findings from this research, the following recommendations were made:

1. Awareness on the importance of wildlife (primates') conservation should be carried out in the state to reduce the rate of ignorance on primate conservation.

2. Efforts should be made to adequately protect the study areas, since they are still one of the few remaining locations in the state where some valuable tropical and indigenous trees species can be found as their home to most primates.

3. Federal University of agriculture Makurdi should partner with Benue state government in order to enlist the status of Forest Reserves in the state for future use as tourist/recreational areas. 
International Journal of Agriculture, Environment and Bioresearch

Vol. 5, No. 03; 2020

ISSN: $2456-8643$

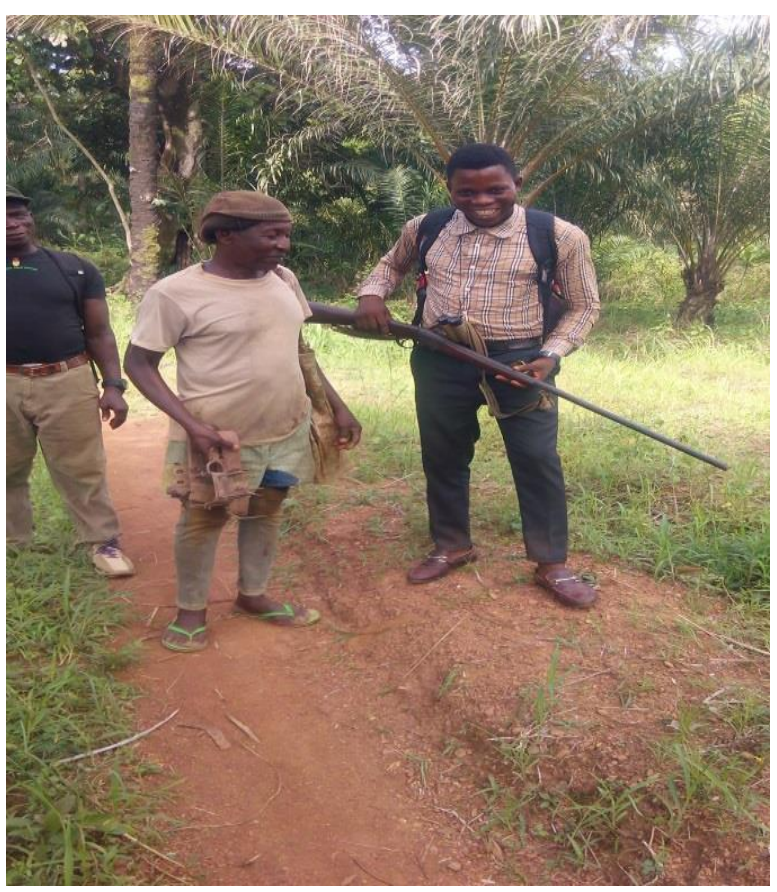

Plate 1: A hunter encountered in Ipinu-igede Forest Reserve

Source: Field survey, (2018)

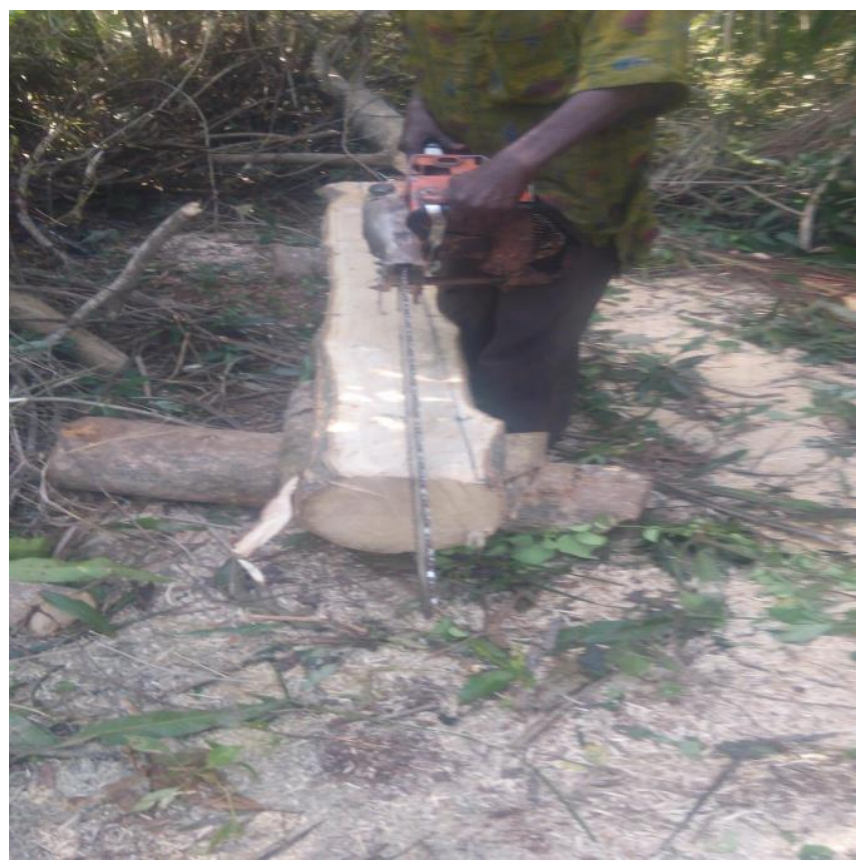

Plate 2: logging activity sighted in Yaaiwa Forest Reserve.

Source: Field survey, (2018) 


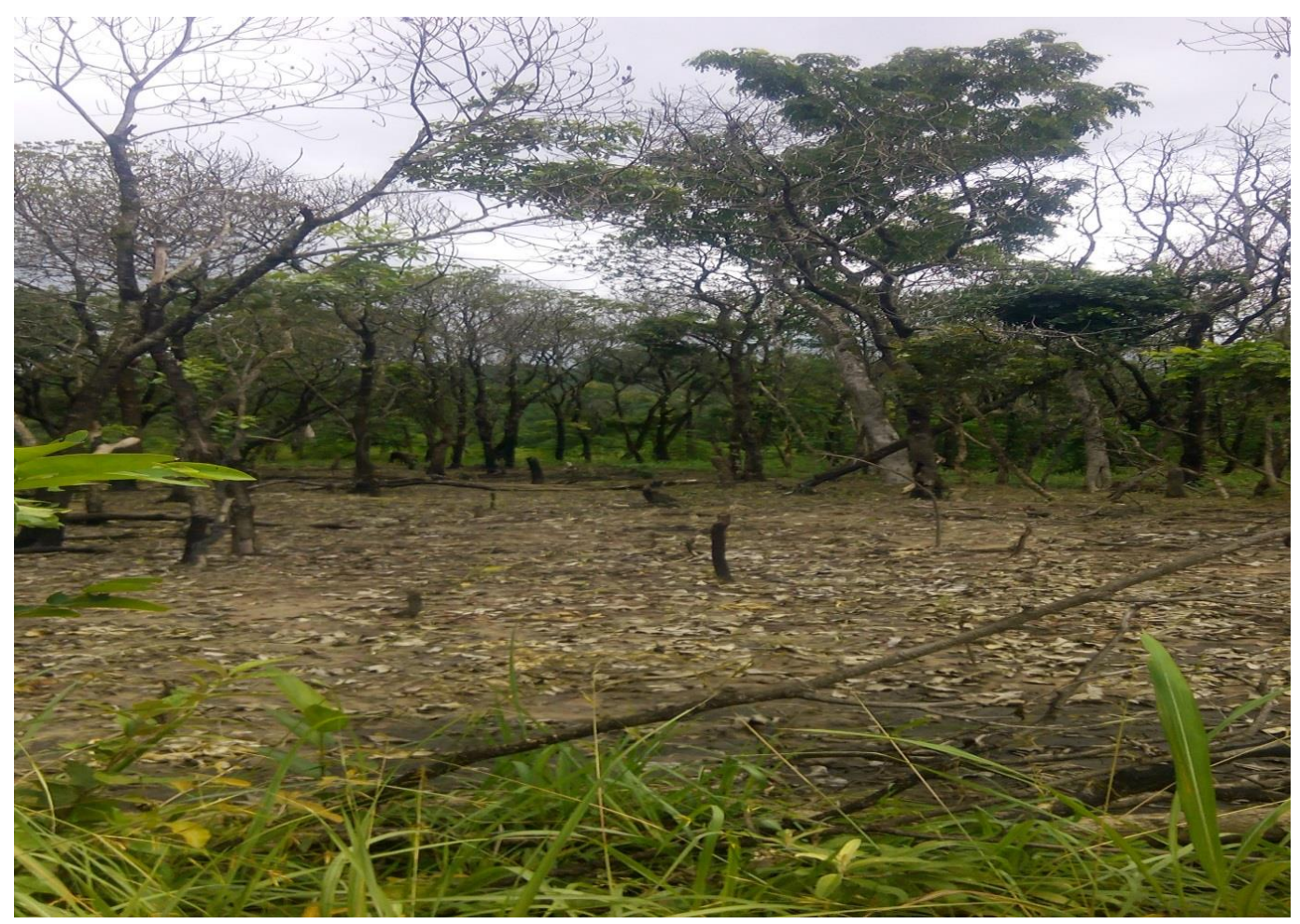

Plate 3: Massive Deforestation by burning to clear land for farm work inside Yaaiwa Forest Reserve.

Source: Field survey, (2019).

\section{REFERENCES}

Ajayi, S., Edet, D.I., Bukie, J.O. (2011.) Population Density of the white Throated Monkey (Cercopicthecus erythrogaster) in Okomu National Park, Edo State Nigeria. Journal of Agriculture, Forestry and the Social Sciences. Vol. 9, No.2, 175-182.

Ajayi, S., Eniang, E.A., and Bukie, J.O. (2012) Effect of Hunting Activities on the Population of White-Throated Monkey (cercopithecus erythrogaster) in Okomu National Park, Edo State, Nigeria. CRUTECH Journal of Science, Engineering and Technology 1 (2), September 2012: 16 .

Baker, L.R., A.A. Tanimola, O.S. Olubode \& D.L.Garshelis. 2019. Distribution and abundance of sacred monkeys in Igboland, southern Nigeria.American Journal of Primatology 71: 574-586.

Baker, L.R., Arnold, T.W., Olubode, O.S. and Garshelis, D. L. (2015). Considerations for using occupancy surveys to monitor forest Primates: a case study with Sclater's Monkey (Cercopithecus sclateri). Population ecology 53 (4)251-262.

Bassey, E. (2012): Afi Mountain Wildlife Sanctuary Cyber tracker Patrol Report. JanuaryMarch, 2012., Unpublished 11p. 
forest landscapes. Diversity and Distributions 19: 1339-1352.

Bennett, A. J. (2015). New era for chimpanzee research: broad implications of chimpanzee research decisions. Developmental Psychobiology 57: 279-288.

Cowlishaw, G. and Dunbar, R. I. M. (2000). Primate Conservation Biology. Chicago, IL: University of Chicago Press.

Edet, D. I., Akinyemi, A.F., Uloko, I.J., and Ikpi, G.U.(2006): Women and Biodiversity utilization in Enclaves of Cross River National Park, Nigeria. Journal of Tropical Forest Resources. Vol.22 (2006): 148-157.

Hatcher,et al. 2004 Species survival in fragmented landscapes: where are we now? Biodivers Conserv 13:1-8.

Henry, M. Ijeomah, Augustine, U. Ogogo and Daminola Ogbara. (2012) Analysis of Poaching Activities in Kainji lake National Park of Nigeria. Environment and Natural Resources Research Vol.3, No.1;2012:51-61.

Joyner, et al. (2015). No more monkeying around: primate malaria model systems are key to understanding Plasmodium vivax liverstage biology, hypnozoites, and relapses. Frontiers in Microbiology 6: 1-8.

Kent and coker, 1992. Co-existence between the traditional societies and wildlife in western Serengeti, Tanzania: its relevancy in contemporary wildlife conservation efforts. Biodiversity and Conservation 17: 1861-1881.

Lameed,G.A. 2010: Tropical Ecology, Assessment, And Monitoring (TEAM) Initiative. Primate Monitoring Protocol.Conservation International, Washington D.C. p. 2-10.

Kent and P. Coker. 1992. Vegetation Description and Analysis: A Practical Approach, Chichester. UK: John Wiley \& Sons.

Mittermeier, R. A. et al.2009: Primates in peril: The world's 25 most endangered primates 20082010. Primate Conservation 24, 1-57.

Oates, J.F., L.R. Baker \& Z.J. Tooze. 2008. Cercopithecus sclateri. IUCN Red List of Threatened Species. Version 2013.1. Available from: http://www.iucnredlist.org/details/4229.

Oates, J.F., P.A. Anadu, E.L. Gadsby \& J.L. Werre. 1992. Sclater's guenon-a rare Nigerian monkey threatened by deforestation. National Geographic Research \& Exploration 8: 476-491.

Ogar, D. A. 2009. Fundamentals of Forestry and Wildlife Management in Nigeria. Unical Printing Press, University of Calabar, Calabar. 122p.

Ogar, D.A. (2009). Fundamentals of Forestry and Wildlife Management in Nigeria. Unical Printing Press, University of Calabar, Calabar. 122p 
Ogogo, A.U., Eniang, E.A., and Ettah, U.S. (2010): Habitat Utilization and conservation status of the Cross River Gorilla (Gorilla gorilla diehli) in Afi mountain Wildlife Sanctuary. Cross River State, Nigeria. International Journal of pure and Applied Sciences. Vol.3, No. 3 P.121-125.

Oladeji, S.O., Afolayan, T.A., and Agbelusi, E.A. (2010): Anthropogenic Activities as they affect the management of Old Oyo National Park: Sustainable Development Programme's Antidote. Onyekwelu, J. C., Adekunle, V. A., and Oke, D. O. (Editors). Proceedings of the Second Biennial National Conference of the Forest and Forest Products Society, field at the Federal University of Technology, Akure, Nigeria. 26-29th April, 2010. P.513-520.

Peres, C. A. (1989): General Guidelines For Standardizing line-Transect Surveys Of Tropical Forest Primates. Neotropical Primates 7(1): 11-16.

Richard, E.P., L.D. Wolfe \& A. Fuentes., 1987: Ethnoprimatology: contextualizing human and nonhuman primate interactions.

Schwitzer et al., (2014). Study on understanding the causes of biodiversity loss and the policy assessment framework. European Commission Directorate-General for Environment. 